\title{
Semideciduous Seasonal Forest Production of Leaves and Deciduousness in Function of the Water Balance, LAI, and NDVI
}

\author{
Thomaz Correa e Castro da Costa, ${ }^{1}$ João Herbert Moreira Viana, ${ }^{1}$ and Juliana Leite Ribeiro ${ }^{2}$ \\ ${ }^{1}$ Embrapa Milho e Sorgo, Road MG 424, km 45, 35701-970 Sete Lagoas, MG, Brazil \\ ${ }^{2}$ Universidade Federal de São João Del Rei, Campus Sete Lagoas, Road MG 424, km 47, 35701-970 Sete Lagoas, MG, Brazil \\ Correspondence should be addressed to Thomaz Correa e Castro da Costa; thomaz.costa@embrapa.br
}

Received 28 August 2013; Revised 19 December 2013; Accepted 4 February 2014; Published 31 March 2014

Academic Editor: Panos V. Petrakis

Copyright (C) 2014 Thomaz Correa e Castro da Costa et al. This is an open access article distributed under the Creative Commons Attribution License, which permits unrestricted use, distribution, and reproduction in any medium, provided the original work is properly cited.

\begin{abstract}
This study investigated the relationship between leaf production, litterfall, water balance, Leaf Area Index (LAI), and Normalized Difference Vegetation Index (NDVI) in semideciduous forests. The goal was to model this phenomenon to obtain the estimates of this component as an additional compartment of the ecosystem carbon sink. The tests were conducted in eight semideciduous forest fragments. Twenty-four permanent plots were monitored monthly and LAI measurements and weighing of litterfall deposited in nets were conducted for a period of thirteen months. In this period, Landsat 5 and IRS satellite images were obtained and processed for generation of NDVI. The water balance was calculated for each day. The relationship among the variables "leaf dry weight," "LAI," "NDVI," and "water balance" was verified and a regression model was built and evaluated. The deciduous phenomenon can be explained by hydric balance, and LAI and NDVI are ancillary variables. The tendency of the variables in the period of 13 months was explained by quadratic functions. The varied behavior among the monitoring sites helped to know differences in the deposition of leaves. This study showed that only the leaf component of the litterfall of a semideciduous forest in tropical climate can capture 4 to $8 \mathrm{Mg} \cdot \mathrm{ha}^{-1} \cdot \mathrm{yr}^{-1}$ of $\mathrm{CO}_{2}$ and this amount can be estimated using climate, biophysics, and vegetation index variables.
\end{abstract}

\section{Introduction}

The sprouting, development, blooming, fruit bearing, and senescence phases determine the phenology of plant species. In forest ecosystems, the sprouting and leaf growth, the senescence, and the leaf fall are crucial for their maintenance and for survival through the nutrient cycling. The fall of leaves, branches, flowers, and fruits supplies organic material to the surface layer of the soil nourishing the plant species. By means of this process, nutrients are deposited and mineralized, maintaining the soil fertility in these ecosystems [1$3]$. The type of vegetation and the environmental conditions influence the distribution, quantity, and quality of these materials, which form the litterfall $[4,5]$.

The accumulated litterfall is all the deposited material on the surface of the forest soil for a determined period, which may be measured by the deposition in collectors of prefixed sizes during preestablished time intervals [6].
The deciduousness phenomenon is governed by the species occurring in each ecosystem. Such phenomenon is induced by environmental conditions, especially by temperature and water stress [7], according to the regional climate. Therefore, Seasonal Semideciduous Forest is a type of vegetation conditioned by the climatic seasonality, which may be tropical, defined by the rainfall regime, with a rainy season and a dry season, with dynamics that depend on the soil water status; or subtropical, determined by low winter temperatures [8]. In temperate climates, the seasonality is severe and the phenology of the species is forcefully dependent on the temperature $[7,9]$.

In ecosystems driven by water or temperature deficiency, the quantity of material that falls from the canopy, forming the litterfall, reaches a rate of tons per hectare/year, then the forest starts producing leaves again by the beginning of the rainy season or with the increase of the temperature, renewing the lost biomass. 
One of the purposes of litterfall deposition estimation is to present the efficiency of the natural ecosystems in providing the soil with the necessary nutrients for its maintenance [10]. Another purpose is to evaluate its role as a carbon sink, which may be an important environmental service that justifies its preservation.

There are rare cases in the many studies about deciduousness and nutrient cycling monitoring that relate this monitoring with biophysical and orbital variables, which is the way of estimating these phenomena. Identifying the behavior patterns in these processes will make its modeling possible.

On the other hand, many attempts to detect the vegetation phenological patterns by remote sensing, in order to understand the year-to-year cycling pattern of the carbon in the terrestrial ecosystems, have been made, especially after the release of the MODIS sensor, [11], and for the calibration quality and the products provided such as LAI and fAPAR [12]. Zhang et al. [13], using MODIS data on a continental scale, were able to detect phenological leaf growth and dormancy stages, which are related to temperature, occurrence periods, and the latitude.

The relationship of remote sensing vegetation index to the leaf area is well known, especially in natural vegetation [1424]. The leaf area is a key biphasic variable, which is related to the physiologic processes of the plant, such as the production and the consumption of the plant phytomass through the absorbed electromagnetic radiation, photosynthesis, respiration, and transpiration. One of the forms to estimate the leaf area in the field is by the measurement of the electromagnetic energy transmission rate using specific instruments like LAI 2200 [25-27], or through direct methods, such as decline of leaf litter component [28].

The empiric relation between LAI (Leaf Area Index) and NDVI (Normalized Difference Vegetation Index) is affected by NDVI saturation in dense plant coverage [21], which occurs specially in ombrophilous typologies.

One of the experiments that approached the orbital index relation with the deciduousness was done by Wang et al. [16], who related NDVI and LAI in deciduous forest sites, taking into consideration that LAI was acquired from two methods. One was the direct method, using the weight of the periodically collected leaves per unit of surface area, with the leaf area obtained by calibration with the simple measurement of small samples, and the indirect method using the inverse model of the Beer-Bouguer-Lambert Law, from the effect of the zenithal angle in the extinction coefficient and in the clumping index, having the global daily radiation above and below the canopy as input.

The deciduous phenomenon studied is controlled by the tropical climatic seasonality, which is defined by the rainfall regime. The climatic variations, especially precipitation and evapotranspiration, determine, along with the physiological behavior of the deciduous species and the edaphic conditions, the moment when the deciduousness increases and the leaf production is reduced and the period in which the deciduousness is reduced and the leaf production is increased. The water balance (periods with water excess or deficiency) is the main conditioning of this phenomenon. Potithep et al. [29] and

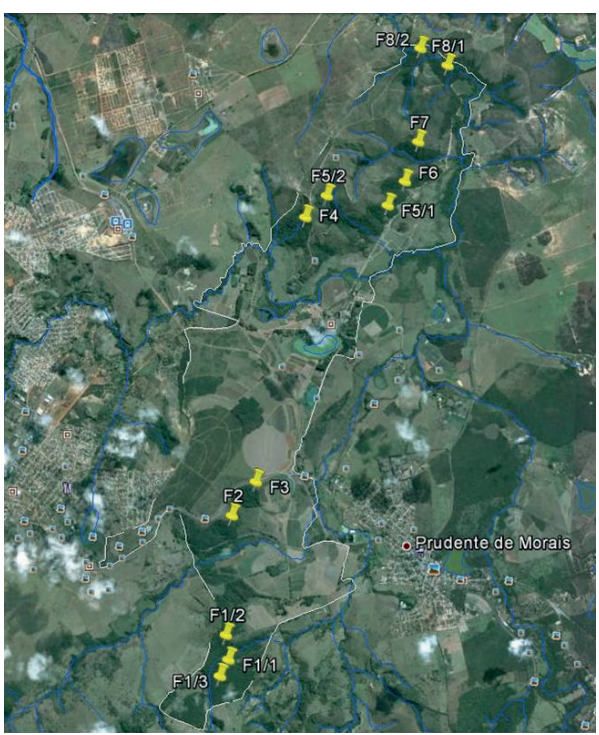

Figure 1: Location of the study sites in each fragment of the Embrapa Experimental Farm, Sete Lagoas, MG, Brazil.

Kale et al. [30] established two stages in deciduous tropical forests, leaf growth, and senescence. In deciduous temperate forests, three stages were observed, whereas in the summer, a period of leaf permanence occurs [16].

In the litterfall deposition and leaf production, the leaf area may be a descriptor of this phenomenon, as it has a direct relationship with the leaf loss (LAI reduction) and with seeding and leaf growth (LAI increasing). Both processes, deciduousness and leaf production, show little temporal intersection under these climatic conditions.

The objective of this work is to study the deciduousness relationships and the leaf production, water balance, leaf area, and the NDVI, with the intention of modeling the annual litterfall production rate in a semideciduous seasonal forest. It will be therefore possible to estimate the nutrient deposition and the carbon fixation through this phenomenon.

\section{Materials and Methods}

2.1. Study Site. The study was conducted in forest fragments where a phytosociological inventory was done. The inventory design had twenty-four $20 \times 20$ meter permanent plots, in eight fragments of deciduous seasonal forest, in a Cerrado Bioma, at the Experimental Farm of Embrapa Maize and Sorghum, which is located in the city of Sete Lagoas, MG, Brazil (Figure 1), characterized by the parameters of Table 1.

The forest fragments have been monitored for the nutrient balance and carbon fixation, including the litterfall decomposition rate, soil classification by profiles, fertility analyses, soil granulometry, water retention curves, infiltration tests, and microbial activity. The bush and arboreal species with Diameter at Breast Height $(\mathrm{DBH})$ greater than $5 \mathrm{~cm}$ were measured and identified.

Fragment 1 is a forest after regenerated pasture, which was verified with the aid of an aerial photo from 1949, 
TABLE 1: Coordinates $(X, Y)$ UTM/ 23 Zone WGS84 of the 1st permanent plot in the fragments, geometric altitude $(Z)$, declination in degrees $(\mathrm{Decl})$, number of permanent plots (Parc), individual density $\left(\right.$ ind $\left.\cdot \mathrm{m}^{-2}\right)$, basal area $(B)$, volume $($ Vol), average tree height $(H)$, Shannon index $\left(H^{\prime}\right)$, and Simpson dominance index $(C)$.

\begin{tabular}{lccccccccccc}
\hline Frag & $X(\mathrm{~m})$ & $Y(\mathrm{~m})$ & $Z(\mathrm{~m})$ & Decl $\left(^{\circ}\right)$ & Parc & ind $\cdot \mathrm{m}^{-2}$ & $B\left(\mathrm{~m}^{2} \cdot \mathrm{ha}^{-1}\right)$ & $\mathrm{Vol}\left(\mathrm{m}^{3} \cdot \mathrm{ha}\right.$ & & $H(\mathrm{~m})$ & $H^{\prime}$ \\
\hline 1 & 585634 & 7844330 & 888 & 6.7 & 6 & 0.108 & 15.0 & 101 & 8.8 & 2.84 & 0.091 \\
2 & 585747 & 7846422 & 847 & 8.2 & 3 & 0.135 & 25.4 & 179 & 9.8 & 2.95 & 0.076 \\
3 & 586120 & 7846925 & 827 & 5.0 & 1 & 0.120 & 26.0 & 201 & 9.7 & 2.6 & 0.087 \\
4 & 587084 & 7850907 & 851 & 12.7 & 3 & 0.150 & 23.0 & 209 & 9.5 & 2.99 & 0.079 \\
5 & 588363 & 7851128 & 800 & 9.5 & 4 & 0.103 & 26.0 & 216 & 10.7 & 3.26 & 0.047 \\
6 & 588458 & 7851281 & 787 & 8.8 & 3 & 0.083 & 20.0 & 180 & 10.8 & 2.97 & 0.065 \\
7 & 588720 & 7851999 & 813 & 26.5 & 3 & 0.058 & 17.3 & 177 & 10.7 & 2.69 & 0.077 \\
8 & 589268 & 7853121 & 763 & 4.2 & 4 & 0.153 & 30.4 & 312 & 10.6 & 3.45 & 0.046 \\
\hline
\end{tabular}

TABLE 2: Collection dates of the Litterfall, LAI measurement, and Landsat 5 images (08/20/11-09/21/11) and IRS (08/02/12-09/11/12), and respective days of the period (01/01/11-12/31/12).

\begin{tabular}{|c|c|c|c|c|c|c|}
\hline \multicolumn{3}{|c|}{$\operatorname{Dlw}\left(\mathrm{g} \cdot \mathrm{m}^{-2}\right)$} & \multicolumn{2}{|c|}{$\operatorname{LAI}\left(\mathrm{m}^{2} \cdot \mathrm{m}^{-2}\right)$} & \multicolumn{2}{|c|}{ NDVI } \\
\hline Date & Julian day & Gather. Period & Date & Julian day & Date & Julian day \\
\hline & & & & & $20 / 08 / 11$ & 232 \\
\hline $13 / 09 / 11$ & 256 & 29 & & & 05/09/11 & 248 \\
\hline $11 / 10 / 11$ & 284 & 28 & 19/10/2011 & 292 & $21 / 09 / 11$ & 264 \\
\hline 16/11/11 & 320 & 36 & $16 / 11 / 2011$ & 320 & & \\
\hline $14 / 12 / 11$ & 348 & 28 & $12 / 12 / 2011$ & 346 & & \\
\hline $16 / 01 / 12$ & 381 & 33 & $15 / 01 / 2012$ & 380 & & \\
\hline $14 / 02 / 12$ & 410 & 29 & $10 / 02 / 2012$ & 406 & $08 / 02 / 12$ & 404 \\
\hline $15 / 03 / 12$ & 440 & 30 & $13 / 03 / 2012$ & 438 & $03 / 03 / 12$ & 428 \\
\hline $15 / 04 / 12$ & 471 & 31 & $17 / 04 / 2012$ & 473 & $20 / 04 / 12$ & 476 \\
\hline $14 / 05 / 12$ & 500 & 29 & 08/05/2012 & 494 & & \\
\hline $15 / 06 / 12$ & 532 & 32 & $20 / 06 / 2012$ & 537 & $01 / 07 / 12$ & 548 \\
\hline $15 / 07 / 12$ & 562 & 30 & $13 / 07 / 2012$ & 560 & $25 / 07 / 12$ & 572 \\
\hline $14 / 08 / 12$ & 592 & 30 & $14 / 08 / 2012$ & 592 & & \\
\hline $13 / 09 / 12$ & 622 & 30 & $13 / 09 / 2012$ & 622 & $11 / 09 / 12$ & 620 \\
\hline
\end{tabular}

with a small diversity of species. The soils in this area are of the Haplohumult and Kandiudox classes of USA Soil Taxonomy [32]. Fragment 2 is transition between the Savanna and Semideciduous Seasonal Forest on the Haplustox soil class; Fragment 3 is on the Inceptic Hapludox soil class and a water Table 2 meters deep; Fragments 4, 5, and 6 are remnants of the Semideciduous Seasonal Forest on Inceptic Haplustox, Inceptic Eutrustox, and Humic Haplustox soils. The permanent plot in Fragment 7 has a great occurrence of bush vegetation, low tree density, and the predominance of individuals of great size on an Inceptic Haplustox soil class. Fragment 8 is close to water bodies on Inceptic Haplustox and on Kanhaplustalf soil classes. All the soils present high to very high saturation by aluminum (Al\%), and low to very low base saturation $(V \%)$ in the subsurface horizons, with the exception of Site 2 in Fragment 8. The horizon A of those soils is the only eutrophic horizon.

2.2. Water Balance. In 2011, the average temperature for the year was $22.24^{\circ} \mathrm{C}$ with an annual precipitation of $1446.3 \mathrm{~mm}$ and potential evapotranspiration of $1073.2 \mathrm{~mm}$.
The water balance of Thornthwaite was calculated from 2011 to October 2012 with daily data of PET (Potential Evapotranspiration) calculated by Penman-Monteith [33] and the precipitation, with data obtained from the INMET Climatologic Station, which is installed at the Embrapa Experimental Farm. In order to calculate the daily water excess and the water deficiency, an available water capacity of $150 \mathrm{~mm}$ was used and the methodology described in Pereira et al. [34] was carried out by the development of a VBA routine (Visual Basic for Application).

2.3. Deciduousness Measurement. In order to measure the deciduousness data, 24 permanent plots of the phytosociological inventory were used. The gathering of the deposition of litterfall in the nets was done in the intermediate days of each month. After the installation of the $1 \mathrm{~m} \times 2.5 \mathrm{~m}$ nets in the field, the length, width, and diagonals of each net were measured to calculate their exact area, since their installation produced small variations in the original dimensions. Therefore, each net had its own area to measure the weight of the leaves in $\mathrm{g} \cdot \mathrm{m}^{-2}$. 
During the gathering, a screening was made to discard the branches, and the seeds and fruits were separated for the germination tests. The leaves were weighted on an analytical scale to obtain the fresh mass, moisture (\%), and the dry mass (g) after the sample-weight stabilization in an oven at $65^{\circ} \mathrm{C}$.

The data for the dry leaves in $\mathrm{g} \cdot \mathrm{m}^{-2} \cdot$ net $^{-1}$ were summarized by fragment, which is an average of the installed nets in the permanent plots of each fragment.

To obtain the deciduousness variation rate by fragment, the observed data of the dry leaf weight $\left(\mathrm{g} \cdot \mathrm{m}^{-2}\right)$ were adjusted to the number of days by quadratic equations, and the first derivative of each equation was taken, which corresponds to the variation rate between the recurrent periods. Thus, relationships of deciduousness variation rates were obtained with the variables, water excess, and deficiency ( $\mathrm{mm}$ ).

2.4. LAI Measurement. In order to measure the leaf area, an LAI 2200 Plant Canopy Analyzer [25] was used, an indirect measurer which uses transmittance for the LAI calculation $\left(\mathrm{m}^{2}\right.$ of leaf $\cdot \mathrm{m}^{-2}$ of soil). The probability of noninterception of light by the canopy, $P(\theta)$, is the function of the length of the coursed path, $S(\theta)$, canopy density, $\mu\left(\mathrm{m}^{2}\right.$ foliage per $\mathrm{m}^{3}$ canopy volume), and $G(\theta)$, the fraction of foliage projected toward $\theta$, given by [25]

$$
P(\theta)=e^{-G(\theta) \mu S(\theta)}
$$

And the exact solution for the density $(\mu)$, proven by [35], is quoted by Li-Cor [25] as follows:

$$
\mu=2 \int_{0}^{\pi / 2}-\frac{\ln P(\theta)}{S(\theta)} \sin \theta \mathrm{d} \theta
$$

In continuous and homogeneous forest ecosystems,

$$
S(\theta)=\frac{h}{\cos (\theta)},
$$

Where $h$ is the height of the canopy. The relation between the density of the leaf area by the canopy volume $(\mu)$ and LAI is:

$$
L=\mu * h \text {. }
$$

Substituting (3) and (4) in (2), yields:

$$
\mathrm{L}=2 \int_{0}^{\pi / 2}-\ln \mathrm{P}(\theta) \cos \theta \sin \theta \mathrm{d} \theta
$$

To procedure of the Lai 2200 it is need the apparent clumping factor:

$$
\omega_{\mathrm{app}}=\frac{2 \int_{0}^{\pi / 2}-(\ln \overline{\mathrm{P}(\theta)} / \mathrm{S}(\theta)) \sin \theta \mathrm{d} \theta}{2 \int_{0}^{\pi / 2}-(\overline{\ln \mathrm{P}(\theta)} / \mathrm{S}(\theta)) \sin \theta \mathrm{d} \theta}
$$

Where $\theta=7,23,38,53,68$ zenithal angles delimited by each ring in the fisheye lens of the sensor.

$$
P(\theta)=\frac{B}{A}
$$

Expression (7) is the transmittance or probability of a light beam passing over the foliage without being intercepted, measured by the ratio between the $B$ readings, obtained below the canopy, and the A readings, before being intercepted by the canopy.

The effective leaf index, $\mathrm{L}_{e}$, is finality computed by

$$
\mathrm{L}_{\mathrm{e}}=L * \omega_{a p p}
$$

To obtain precise measurements with LAI-2200, it is necessary to capture only the diffuse energy. To avoid, or at least, strongly reduce the direct energy captured by the sensor, the readings were made using view cap $45^{\circ}$, under cloudy sky or at dawn or twilight, verifying the luminous stability throughout and after the measurements, which was made by the data tendency analysis after the measurement. The data with tendency were discarded. The readings were always performed on intermediate days of each month, and they started in October 2011, with a reading in each of the collector nets, always in the same position and direction. There were 5 nets in each permanent plot in a total of 120 nets. The LAI was calculated for each permanent plot.

2.5. NDVI Data Processing. To generate NDVI, an atmosphere correction model was used which would allow the use of atmospheric pressure and relative humidity, aiming to obtain the removal of the atmosphere interference with a greater local precision. Three Landsat 5 images were selected (http://www.inpe.br/), as they coincide with their final reception, complementing the period with 7 images of the Indian Remote Sensing Satellite (IRS), a sensor with characteristics closer to Landsat. The main differences between them are the spatial ( $30 \mathrm{~m}$ and $24 \mathrm{~m}$ pixel) and radiometric ( 8 and 7 bits) resolution and a slim difference in the range of the spectral bands. All images are with visibility above $10 \mathrm{~km}$ (information from Air Traffic Control Service bulletin of Confins Airport).

The atmospheric correction was performed with an ATMOSC module of Idrisi Taiga, using the Cost Model.

The Dn Raze [36] was obtained through a procedure which uses a band frequency table, which is available on the electronic spreadsheet at http://www.dsr.inpe.br/downloads.htm, based on the atmosphere correction method of Chaves [37].

The atmosphere optical dimension is the sum of the components Rayleigh scattering, aerosols, water vapor, and typical ozone. Aerosols and typical ozone were not computed due to lack of data. The Rayleigh scattering was adjusted to local height with atmospheric pressure data, using the following expression:

$$
\text { Rayleigh Scattering }=a * \frac{\text { Atm Pressure (local) }}{1013 \text { mbar (sea level) }}
$$

where $a=0.05$ for band $R$ and $a=0.01$ for band NIR ([38], quoted by [39]).

The water vapor component was obtained for the near infrared (NIR), in function of the relative humidity by the linear relation [39]:

$$
\text { Water vapor }=0.0012 * \mathrm{RH} \%+0.016 \text {. }
$$


TABLE 3: Coefficients of determination $\left(R^{2}\right.$ adjusted) for polynomial equations in the observed dry leaf weight $\left(\mathrm{g} \cdot \mathrm{m}^{-2}\right), \mathrm{LAI}\left(\mathrm{m}^{2} \cdot \mathrm{m}^{-2}\right), \mathrm{and}$ NDVI data and respective minimum and maximum points by fragment (sequential day from 01/01/2011).

\begin{tabular}{|c|c|c|c|c|c|c|c|c|c|}
\hline \multirow{2}{*}{ Fragment } & \multicolumn{3}{|c|}{ Dry Leaf Weight (Dlw) } & \multicolumn{3}{|c|}{ LAI } & \multicolumn{3}{|c|}{ NDVI } \\
\hline & $\begin{array}{l}R^{2} \\
\text { adj }\end{array}$ & $\begin{array}{l}\text { Pto } \\
\text { Min. }\end{array}$ & Date & $\begin{array}{c}R^{2} \\
\text { adju }\end{array}$ & $\begin{array}{l}\text { Pto } \\
\text { Max. }\end{array}$ & Date & $\begin{array}{l}R^{2} \\
\text { adj }\end{array}$ & $\begin{array}{l}\text { Pto } \\
\text { Max. }\end{array}$ & Date \\
\hline 1 & 87.39 & 431 & $06 / 03 / 2012$ & 90.73 & 460 & $04 / 04 / 2012$ & 85.05 & 411 & $15 / 02 / 2012$ \\
\hline 2 & 77.92 & 422 & $26 / 02 / 2012$ & 86.25 & 460 & $04 / 04 / 2012$ & 94.03 & 402 & $06 / 02 / 2012$ \\
\hline 3 & 47.6 & - & - & 67.76 & 477 & $21 / 04 / 2012$ & 57.28 & - & - \\
\hline 4 & 77.16 & 440 & $15 / 03 / 2012$ & 65.58 & 464 & 08/04/2012 & 82.75 & 417 & $21 / 02 / 2012$ \\
\hline 5 & 84.11 & 427 & $02 / 03 / 2012$ & 92.38 & 471 & $15 / 04 / 2012$ & 74.33 & 392 & $27 / 01 / 2012$ \\
\hline 6 & 78.86 & 414 & $18 / 02 / 2012$ & 83.41 & 450 & $25 / 03 / 2012$ & 90.33 & 406 & $10 / 02 / 2012$ \\
\hline 7 & 79.98 & 421 & $25 / 02 / 2012$ & 76.32 & 454 & $29 / 03 / 2012$ & 77.03 & 325 & $21 / 11 / 2011$ \\
\hline 8 & 83.19 & 436 & $11 / 03 / 2012$ & 76.84 & 448 & $23 / 03 / 2012$ & 63.18 & 356 & $22 / 12 / 2011$ \\
\hline Ave $^{*}$. & & 427 & $02 / 03 / 2012$ & & 459 & $05 / 04 / 2012$ & & 388 & $02 / 02 / 2012$ \\
\hline
\end{tabular}

* Average without data of Fragment 3.

The geometrical correction was performed using the Geotiff Examiner software, as well as the assistance of the graphic software Inkscape, using a reference point to dislocate each image. As the images contain deformation corrections, this form of correction was more precise compared to the polynomial corrections, even with RMS smaller than $1 / 2$ pixel. In order to extract NDVI in each permanent plot, a rectangle of 9 pixels centralized in the central point of the permanent plot was digitalized.

2.6. Monitoring Period. The three variables, dry leave weight $\cdot \mathrm{m}^{-2}$, LAI $\left(\mathrm{m}^{2} \cdot \mathrm{m}^{-2}\right)$, and NDVI were analyzed in the function of the day of the period from 01/01/2011 to 2012 . The analyses period started in August 2011 (when the leaves start to accumulate) until September 2012 (Table 2). From the 1,560 visits to the nets in this period, 58 correspond to nets damaged by thick fallen branches or damaged by animals. Fourteen were discarded because they correspond to outliers. So, 1488 leaf weight data by period were used. Of the 289 LAI values calculated per permanent plot, 7 were discarded as outliers. And of the 276 NDVI extracted values, 3 were classified as outliers. During the collection periods, the accumulation of leaves was not exactly of 30 days, with a maximum fluctuation of 36 days between October and November 2011 because of the unexpected rains in the collection period. The decision was made in order not to interpolate the data.

\section{Results}

3.1. LAI and Litterfall. LAI has a strong relationship with the deciduousness in this forest typology, as its value is the consequence of the quantity of leaves in the canopy, so alterations in this quantity directly reflect in the LAI. Figure 2 presents the LAI behavior with the dry leaf weight $\left(\mathrm{g} \cdot \mathrm{m}^{-2} \cdot\right.$ period $\left.^{-1}\right)$. Except for Fragment 3, the tendency was similar to the compared fragments. The increase of LAI indicates that the sprouting and growth of leaves increases until a maximum, synchronic with the reduction of deciduousness, when the latter reaches a minimum, and the reduction of leaf area starts, synchronic with the increase of the deciduousness. In this stage, the deciduousness drives the reduction of LAI, because in this period, the leaf production practically stops.

3.2. LAI and NDVI. The NDVI starts its increase before LAI (Figure 3), probably because of the influence of the understory, which promptly responds to the first rain, before the canopy stars sprouting. This understory does not count on LAI computation, as the sensor is positioned above this vegetation for the readings. The NDVI also decreases before the LAI because before the leaf falls, a gradual depigmentation of chlorophyll takes place and the loss of cellular turgidity in the palisade parenchyma of the leaves increases the reflection of the absorption band by the chlorophyll (red) and decreases the reflection band due to the reduction of the intracellular spaces and the turgidity of the cells (near infrared). This phenomenon reflects on the reduction of the NDVI before the deciduous response detected by the LAI. Maki et al. [17] conducted experiments in a cool-temperate deciduous forest with Modis data and LAI field measurements. They had similar results indicating that the understory influences the comparisons between LAI and NDVI and that in the leaf senescence period, the discoloration of the leaves interferes in the NDVI results before it interferes in the LAI response.

In Fragment 3, due to the subsurface water availability, the NDVI results presented here have an intermediate tendency between the seasonal forest and the ombrophilous forest in the study by Soudani et al. [7], who observed the constancy of the NDVI in an ombrophilous forest of Ghana, throughout the year and abrupt changes in the NDVI in temperate climate forests in the north of Europe, driven by the climatic seasonality by temperature.

It is known that the behavior of the deciduousness of the LAI and NDVI is sigmoidal during a period beyond one year, but in one year, these behaviors can be fit in polynomial models. The best adjustment for the deciduous behavior, LAI and NDVI in the whole period of 13 months (September 2011 to September 2012), was through the second-degree 
polynomial model. The coefficients of determination and their minimum and maximum points, which are the periods of curves inversion, are shown in Table 3.

An average displacement between the NDVI and the LAI may be estimated using its maximum points, around 70 days, which means that the NDVI started its decrease about two months and 10 days before the LAI in this period of the experiment (considering all the fragments, with exception of Fragment 3, which presents a deciduous behavior with a different pattern). It could be verified that the LAI and the NDVI in seasonal forests present a temporal displacement, as the LAI will only be affected later, when the leaves fall. Thus, this is one of the reasons for the temporal relationship of two stages between LAI and NDVI (Figure 4). The greatest complexity in the temporal relation between the NDVI and the LAI was also noticed by Gupta et al. [40], in the cultivation of onions and wheat, who suggested polynomial models of greater order to explain this behavior.

3.3. Litterfall, LAI, and NDVI between the Fragments. An evaluation of consistency between the variables may be obtained by comparing the position of the curves among the fragments (Figures 7, 8, and 9). The NDVI is the descriptor variable with lower precision, due to limitations of spatial and radiometric resolution, cloudiness, and especially the atmospheric interferences when the analyses are temporal. Its use is justified by the acquisition by remote sensing, with no need for field acquisition. For the NDVI in Figure 9, a behavior similar to the curves obtained with LAI is observed; however, one inconsistency was observed. The NDVI for Fragment 1 was one of the highest indexes and is close to that of Fragment 3, which is inconsistent with its expected leaf area. The other fragments presented compatible correspondence between deciduous, LAI, and NDVI values.

The deciduousness relationship with each descriptor variable (water balance, LAI, and NDVI) is linear, according to the results presented in Table 4. Its behavior depends on the water balance and it changes the leaf area and the NDVI for seasonal forest sites in the analyzed period.

3.4. Water Balance and Litterfall. The region where this experiment was carried out has a tropical climatic seasonality. Its rainy season ranges from October to March, and the dry season ranges from April to September. Figure 5 presents the water balance for the study period. The water deficit started on $05 / 14 / 2011$ and reached its maximum of $-156 \mathrm{~mm}$ on $09 / 13 / 2011$, recovering its water excess on $12 / 14 / 2011$. The maximum excess occurred on $01 / 16 / 2012,574 \mathrm{~mm}$, resuming the water deficit on $05 / 14 / 2012$.

The deciduousness responded to the water reserve in the soil with the inversion of the rate of average change in the fall on day $427,03 / 02 / 12$ (Table 3 ). The middle of the rainy period, from the start of the excess (day 348) (2/14/2011) until the start of the deficit (day 500) on 05/14/2012 was on day 424. This indicates that the resuming of the deciduousness increase occurs from the middle of the water excess period and presents small variation among the fragments, with the exception of Fragment 3. This site does not express this behavior due to a shallow water table, which makes it little sensitive to the rain reduction. Therefore, it has the tendency to present a perennial forest with a greater LAI (Figure 9) and an irregular litterfall compared to the other fragments (Figure 2).

The Pearson's meaningful correlations of the water balance variables with the deciduous are presented in Table 4. In order to demonstrate deceleration and acceleration of leaf deposition in function of the soil water reserves, the graphics of the leaf loss variation rate $\left(\mathrm{g} \cdot \mathrm{m}^{-2} \cdot\right.$ period $\left.^{-1}\right)$ are presented in Figure 6. The leaf loss variation rate was obtained by the application of the 1st derivative to the polynomial function, including the water deficit and excess. When the rainy season starts (October), the water deficit is quickly reduced, and the fall rate deceleration takes place. In the water excess stage, the tendency change corresponds with a nonmodeled variation of the phenomenon. Small water deficit intervals in the rainy period appreciably increase the deciduousness, which is not explained by the polynomial function, and which is also observed in the leaf fall graphic in the LAI function (Figure 2).

The behavior is, again, explained by the end of the water excess, when the maximum point of the function is reached. The deciduousness accelerates almost until its stabilization at the end of the dry period in September, when the water deficiency is at its maximum. There is a content of water in the soil between the field capacity and the permanent wilting point which starts this inversion of the curve, and that may vary according to the soil class and depth.

3.5. Regression Model. Although there are variations in the water deficit in each site, determined by the soil class, soil depth, and topographic position, among others, the measurement of the water deficit, site by site, was not possible and would not have a practical effect on the usefulness of the model for other sites. Similarly, climatological variables, such as the wind speed, which influence the deciduousness, were not included since the integration of daily speed data would be another factor to complicate the data acquisition for the estimation. The model must be precise and also practical.

For the linear regression model fitness tests, the data set of Fragment 3 was excluded. To reduce the heterogeneity of the variance of the dry leaf weight variable, the data were transformed to the logarithmic form $\ln (\mathrm{Dlw})$. The model below was reached after the following steps: analysis of Table 4, execution of the regression through the stepwise, backward and forward procedures with the explanatory variables (LAI, NDVI, def, exc, ppt, and etr), and removal of the excess water (exc) and the real evatranspiration (etr), due to its high correlation with precipitation (ppt) and water deficiency (def), respectively, and to avoid multicollinearity problems. Consider the following:

$$
\begin{array}{r}
\operatorname{Dlw}\left(\mathrm{g} \cdot \mathrm{m}^{-2} \cdot \mathrm{month}^{-1}\right) \\
=\exp (8.53+0.17 * \mathrm{LAI}-7.5 * \mathrm{NDVI} \\
-0.01 * \text { def }+0.00048 * \mathrm{ppt}) .
\end{array}
$$




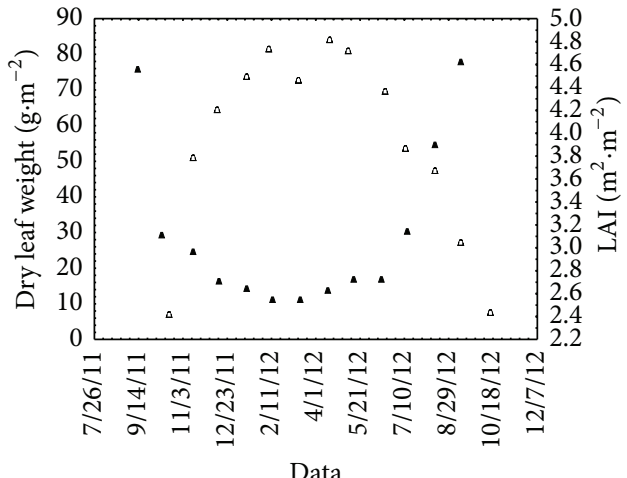

(a)

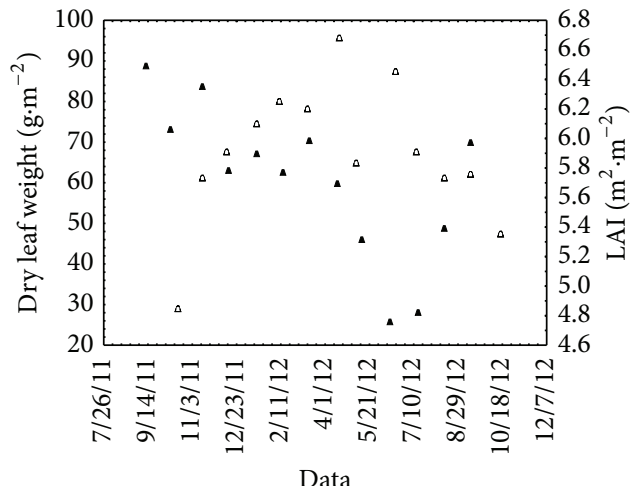

(c)

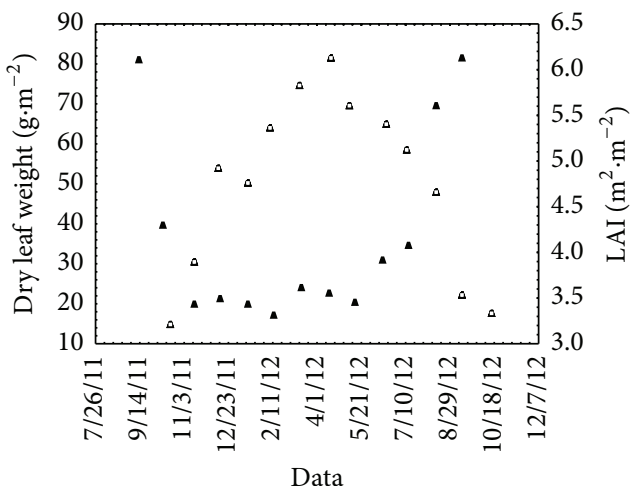

(e)

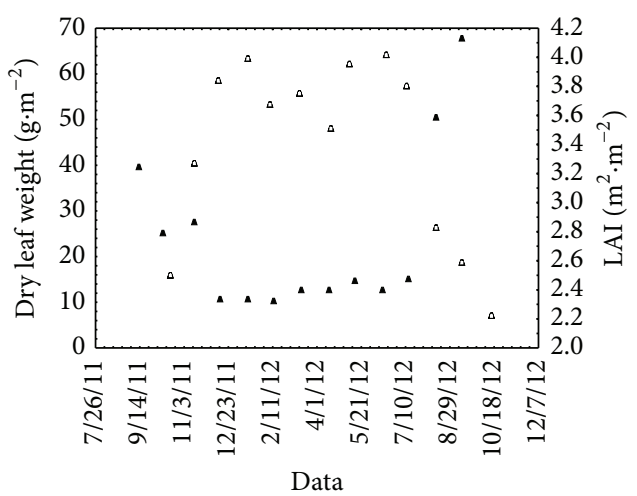

(g)

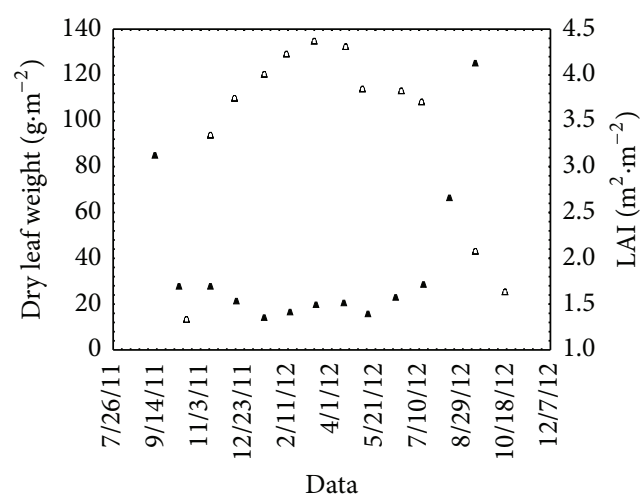

(b)

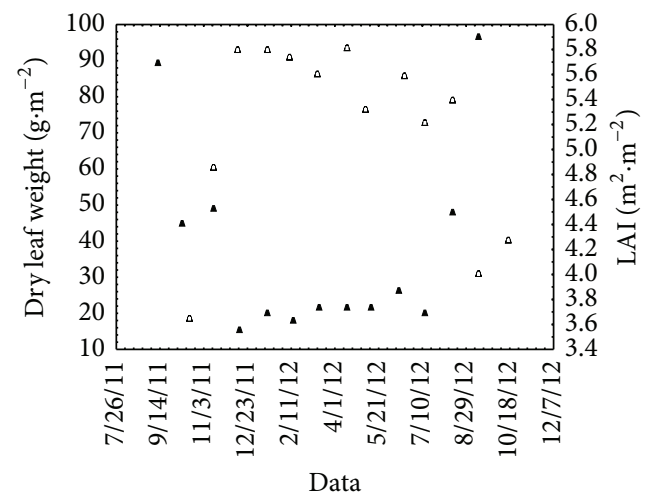

(d)

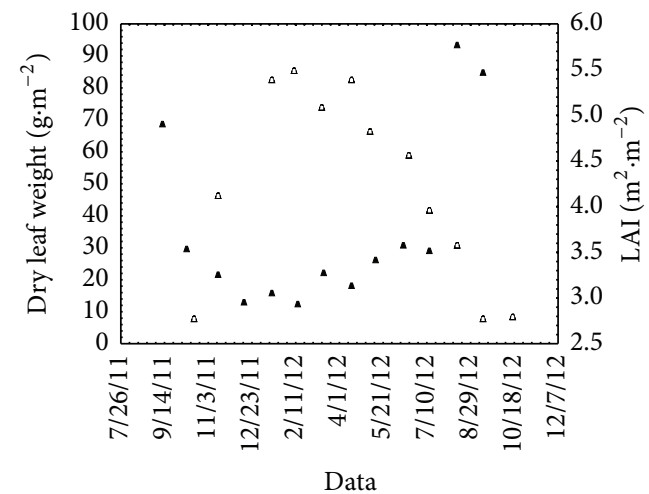

(f)

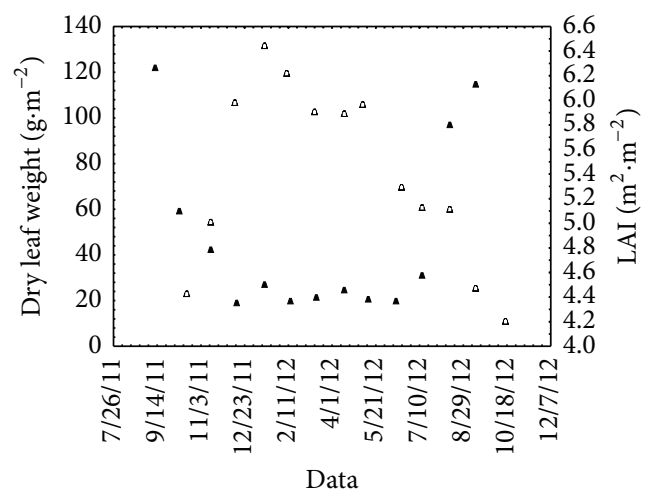

(h)

FIGURE 2: Relation between dry leaf weight $\left(\mathrm{g} \cdot \mathrm{m}^{-2} \cdot\right.$ period $\left.{ }^{-1}\right)$ and LAI $\left(\mathrm{m}^{2} \cdot \mathrm{m}^{-2}\right)$ for the fragments. 


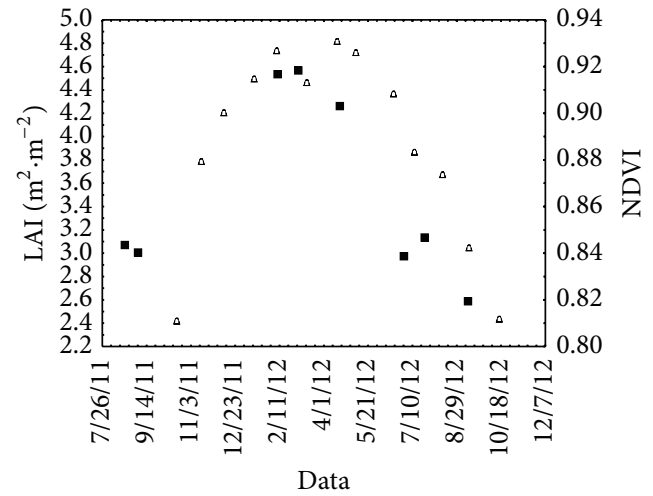

(a)

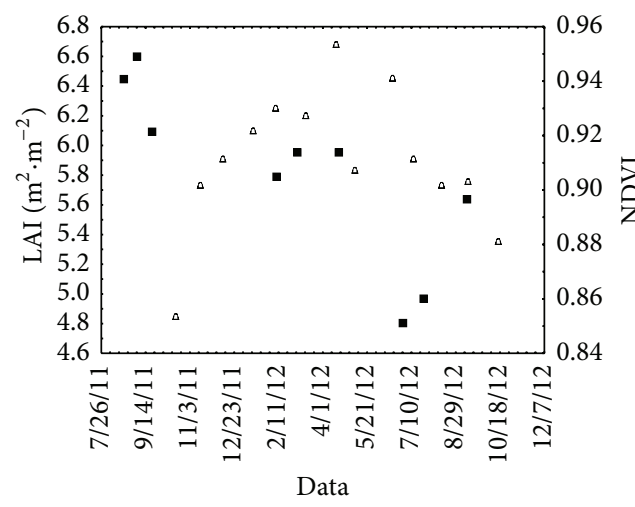

(c)

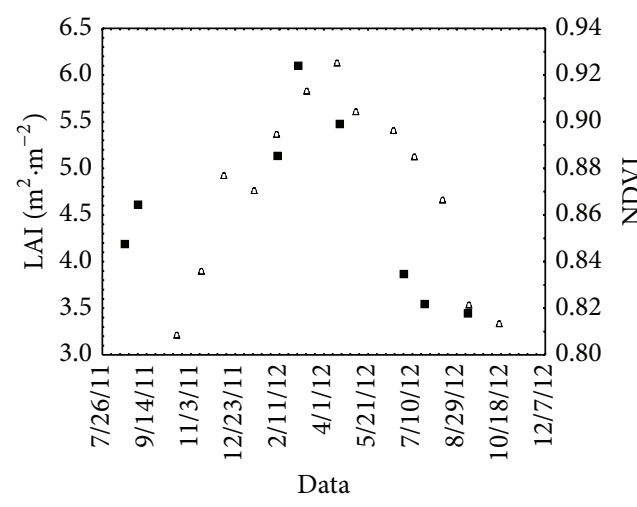

(e)

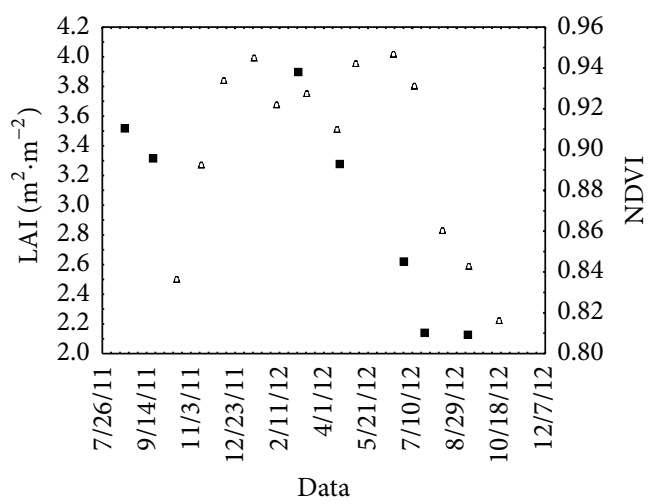

(g)

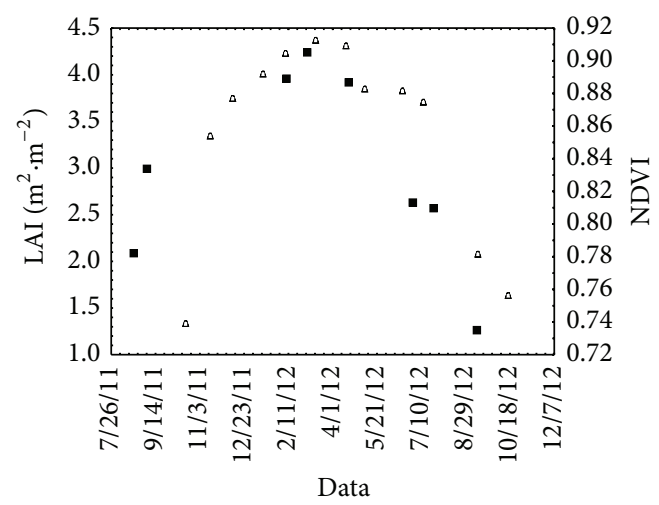

(b)

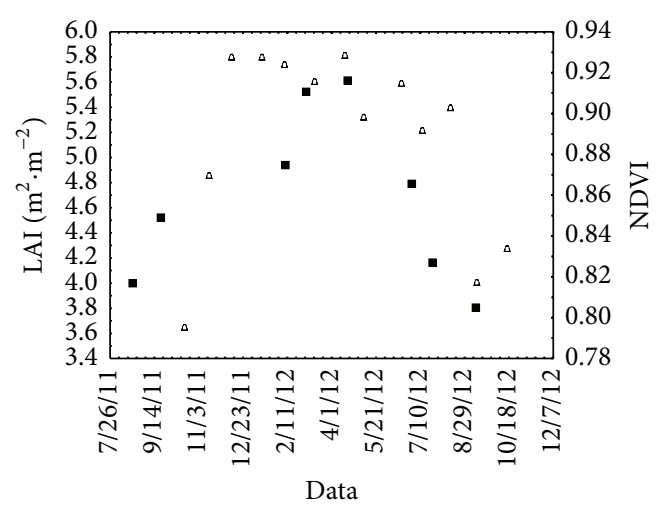

(d)

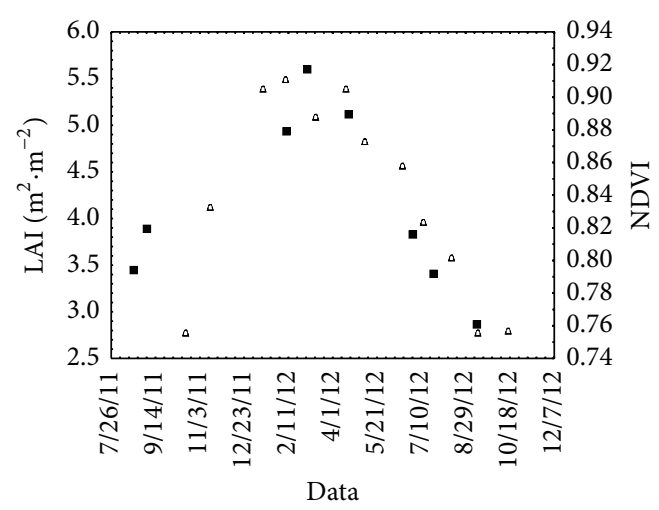

(f)

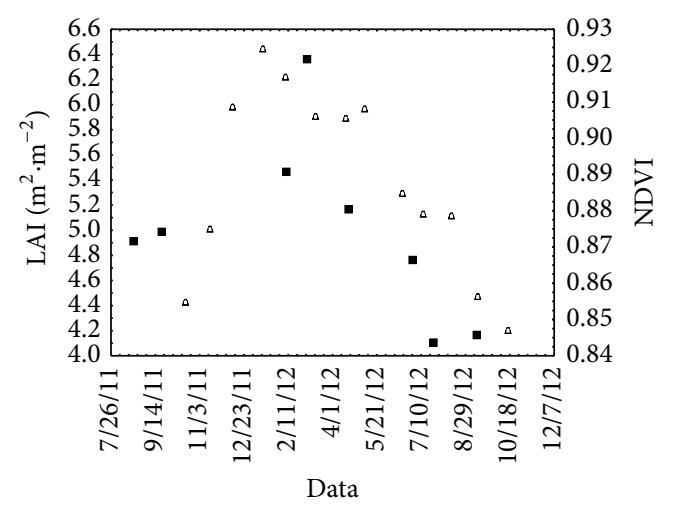

(h)

FIGURE 3: Relations between LAI $\left(\mathrm{m}^{2} \cdot \mathrm{m}^{-2}\right)$ and NDVI for the fragments. 
TABLE 4: Pearson correlation, $\left({ }^{\text {ns }}\right.$ nonsignificant at 0.05 of probability, $\left.n=85\right)$. Correlation of the LAI and the NDVI estimated data for the leaf collection dates using the polynomial equations adjusted to the LAI and the NDVI per fragment. Fragment 3 was removed from this analysis because of a different tendency in relation to the other fragments.

\begin{tabular}{|c|c|c|c|c|c|c|}
\hline & $\begin{array}{l}\text { Dry leaf weight } \\
\left(\mathrm{g} \cdot \mathrm{m}^{-2} / \text { period }^{-1}\right)\end{array}$ & $\begin{array}{c}\text { LAI } \\
\left(\mathrm{m}^{2} \cdot \mathrm{m}^{-2}\right)\end{array}$ & $(r-\operatorname{nir}) /(r+\operatorname{nir})$ & $\begin{array}{l}\text { Water deficiency } \\
\qquad(\mathrm{mm})\end{array}$ & $\begin{array}{l}\text { Water excess } \\
\qquad(\mathrm{mm})\end{array}$ & Precipitation \\
\hline & psflh & LAI & NDVI & DEF & EXC & $\mathrm{ppt}(\mathrm{mm})$ \\
\hline LAI & -0.50 & & & & & \\
\hline NDVI & -0.78 & 0.36 & & & & \\
\hline $\mathrm{DEF}$ & -0.81 & 0.65 & 0.52 & & & \\
\hline EXC & -0.32 & $0.17^{\text {n.s. }}$ & 0.38 & 0.43 & & \\
\hline Ppt & -0.42 & $0.21^{\text {n.s. }}$ & 0.50 & 0.52 & 0.96 & \\
\hline ETR & -0.75 & 0.61 & 0.59 & 0.85 & $0.21^{\text {n.s. }}$ & 0.38 \\
\hline
\end{tabular}

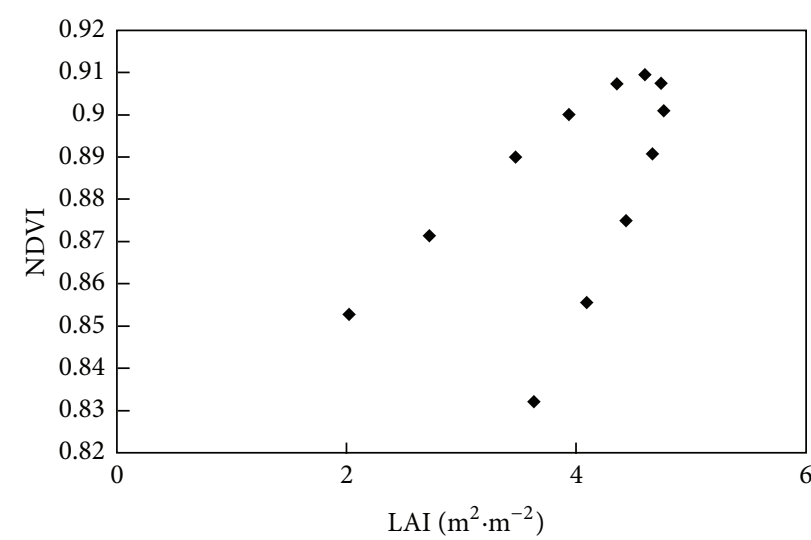

(a)

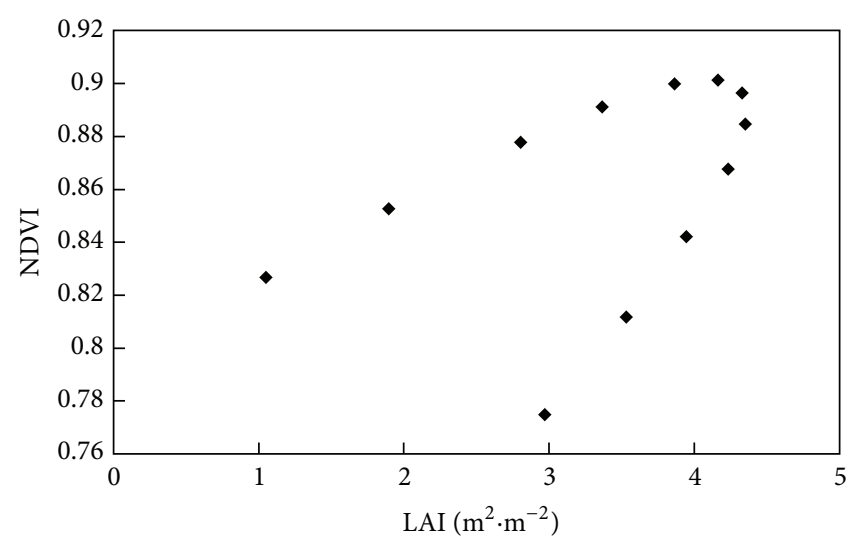

(b)

FIGURE 4: Temporal relation between LAI and NDVI with data adjusted by polynomial curves for Fragments 1 and 2.

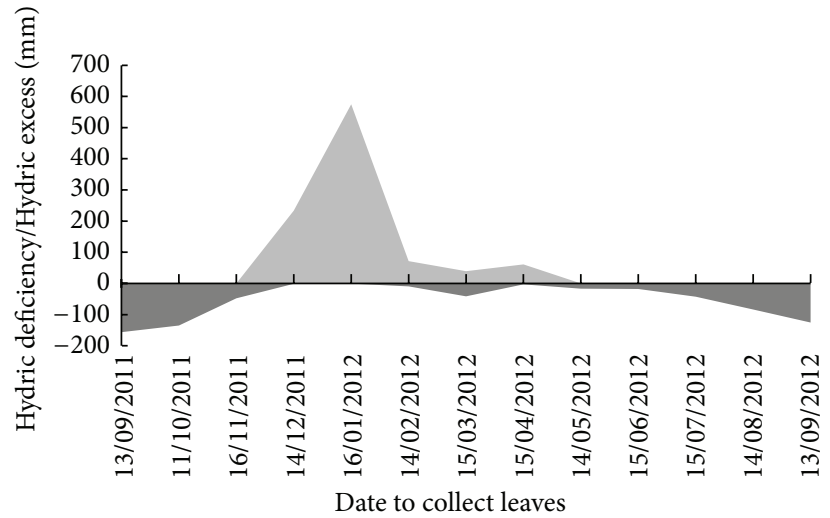

FIgURE 5: Climatologic water balance of Thornthwaite. From September 2011 to September 2012. Observe that the accumulation period is the same as the litterfall collection.

The equation parameters are shown in Table 5. The $R^{2}$ adjustment was $80.2 \%$.

The scatterplots are shown in Figures 10, 11, and 12. They indicate the model adjustment quality through the comparison between the predicted and observed values, the residuals in function of the predicted data and the predictor variables, and the normality of the residuals.

In Figure 10(a), most of the data is out of the 95\% confidence interval; however, the data points present dispersion without bias along the $45^{\circ}$ line. The precision is raised by the compensation within the yearly integration of the monthly predictions. In Figure 10(b), the residuals did not present any tendency with the predicted variable value increase, indicating that there is not a serial correlation, and the heterogeneity of the variances was reduced. It is also verified that the inserted variables are enough to predict the variable Dlw. In Figure 11, the normal distribution of residuals was verified. Figure 12 shows that for most of the values, there is no tendency in the plot of the predicted variables and the residuals, indicating that the proposed model is consistent.

3.6. $\mathrm{CO}_{2}$ Fixation Assessment. The predictions of the $\mathrm{CO}_{2}$ capture by the adjusted deciduousness dynamics equation, for a period of 12 months between 2011 and 2012, were compared to the measured data, for the fragments under study. By means of the sprouting process and the seasonal leaf growth by the leaf biomass production via photosynthesis, and the posterior deposition of this biomass by the deciduousness process, an annual quantity of carbon is deposited in the soil 


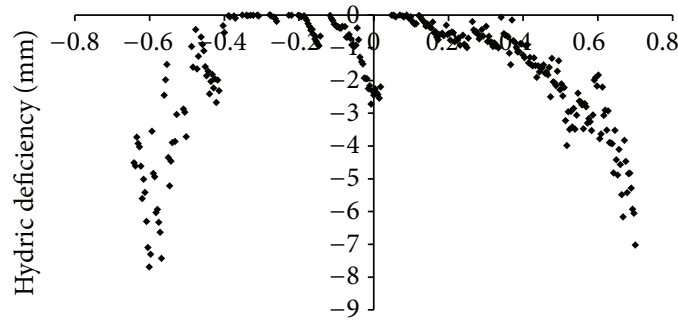

Variation rate of the deciduous $\left(\mathrm{g} \cdot \mathrm{m}^{-2} \cdot \mathrm{month}^{-1}\right)$

(a)

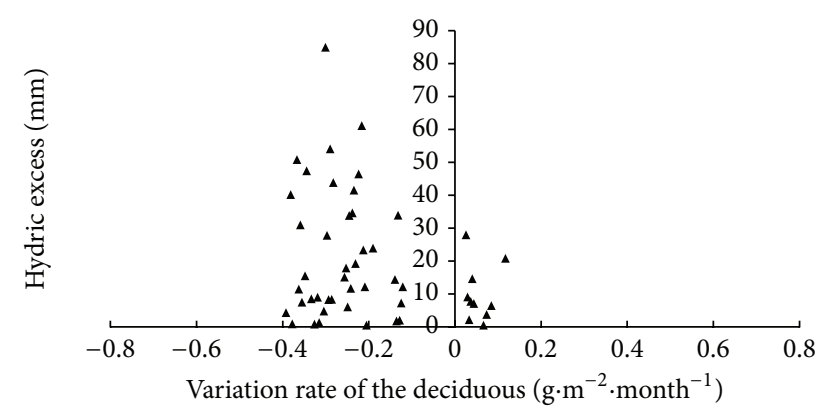

(b)

FIGURE 6: Relationship between the variation rate of the deciduousness with water deficiency and excess in Fragment 1.

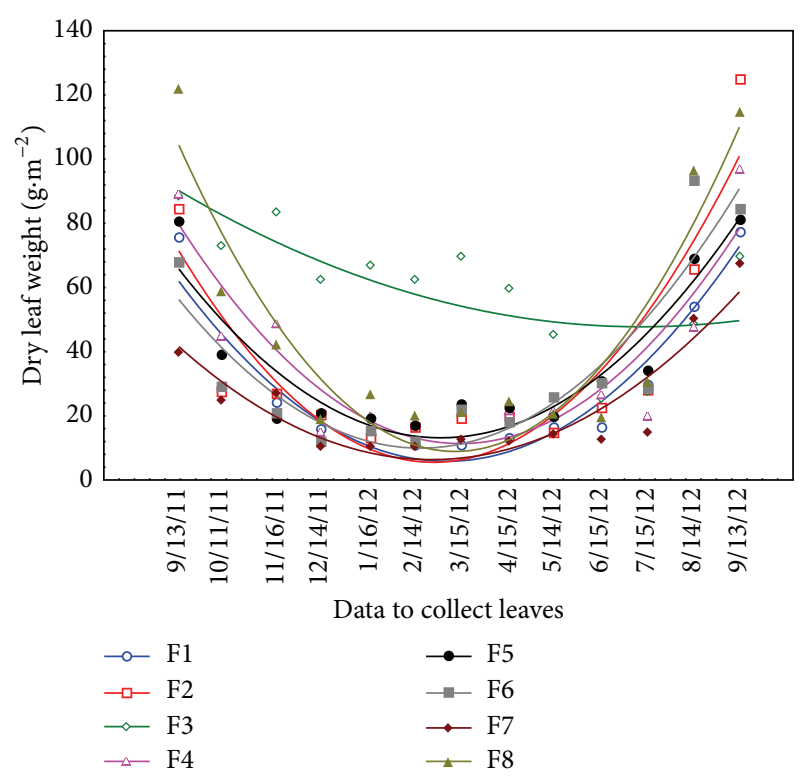

FIGURE 7: Dry leaf weight $\left(\mathrm{g} \cdot \mathrm{m}^{-2}\right)$ with the second-degree polynomial tendency for each fragment.

by the decaying leaves. Thus, for each period of 12 months, including the sequence of rainy and water deficit seasons, a measurable amount of $\mathrm{CO}_{2}$ is captured by this forest typology, adding to the biomass increase in the trunks, branches, and roots, determined by the growth of the vegetation.

The amount of deciduousness may vary in a year to year basis, according to the climatic conditions and to the ecosystem characteristics. Despite the continental events, as El Niño-Southern Oscillation (ENSO), that has influenced Brazil's climatic regime [41], especially the pluviometric distribution, the water balance is expected to be the variable responsible for the year to year variations.

The estimation of annual leaf deposition was accurate, according to the totalization of the monthly data (Table 6). The biggest error, 25\% in Fragment 8, may be verified by observing the dispersion of the LAI and the NDVI in Figure 3. Concerning the fixation of $\mathrm{CO}_{2}$, the smallest capture was in Fragment 7, with 3.7 Mg.ha ${ }^{-1} \cdot \mathrm{yr}^{-1}$, and the biggest was $7.7 \mathrm{Mg} \cdot \mathrm{ha}^{-1} \cdot \mathrm{yr}^{-1}$ in Fragment 8 . The estimated data consider

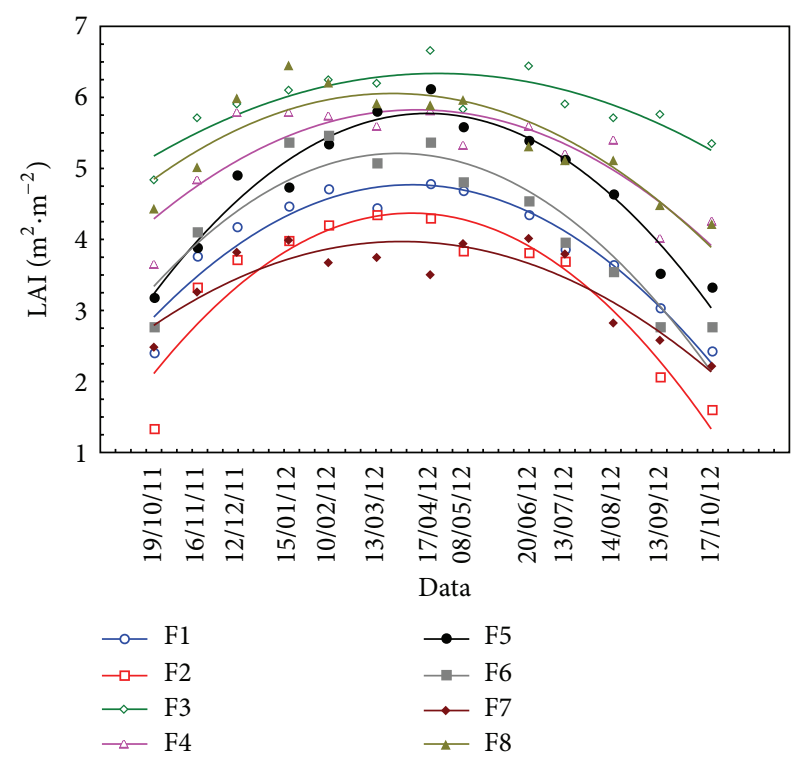

FIGURE 8: LAI $\left(\mathrm{m}^{2} \cdot \mathrm{m}^{-2}\right)$ with second-degree polynomial tendency for each fragment.

TABLE 5: Values (coef.), standard errors of coef. (EP), statistics of Student's test $(t)$, probability of significances $(P$-level) of the equation coefficients for the water deficiency in $\mathrm{mm}$ (def.), NDVI, LAI, and precipitation in $\mathrm{mm}(\mathrm{ppt})$ variables.

\begin{tabular}{lcccc}
\hline & coef. & EP & $t(79 \mathrm{~g} \cdot \mathrm{L})$. & $P$-level \\
\hline a & 8.53107 & 0.817535 & 10.4351 & 0.000000 \\
Def & -0.01004 & 0.000897 & -11.1950 & 0.000000 \\
NDVI & -7.50335 & 0.930050 & -8.0677 & 0.000000 \\
LAI & 0.17132 & 0.037147 & 4.6119 & 0.000014 \\
ppt & 0.00048 & 0.000233 & 2.0578 & 0.042637 \\
\hline
\end{tabular}

Fragment 7 with the smallest capture of $3.7 \mathrm{Mg} \cdot \mathrm{ha}^{-1} \cdot \mathrm{yr}^{-1}$ also, but the largest are Fragments 4 and 6 with 6.4 and $6.3 \mathrm{Mg} \cdot \mathrm{ha}^{-1} \cdot \mathrm{yr}^{-1}$, respectively. Fragment 8 was not so easy to model because it has a riparian forest characteristic, therefore it presented more error. 
TABLE 6: Observed and estimated data of dry leaf weight (Dlw), error of estimation (\%), and fixed carbon in the leaves (C) considering 42.3\% of the biomass (average value of contents in leaves of forest species is obtained by Watzlawick et al., 2011 [31]), captured $\mathrm{CO}_{2}$, by the equivalence of atomic weight between $\mathrm{C}(12 \mathrm{~g})$ and $\mathrm{CO}_{2}(44 \mathrm{~g})$, with the observed data and that estimated by the model.

\begin{tabular}{|c|c|c|c|c|c|c|c|}
\hline Frag & $\begin{array}{c}\text { Dlw } \\
\left(\mathrm{g} \cdot \mathrm{m}^{-2} \cdot \mathrm{yr}^{-1}\right)\end{array}$ & $\begin{array}{l}\text { Dlw estim. } \\
\left(\mathrm{g} \cdot \mathrm{m}^{-2} \cdot \mathrm{yr}^{-1}\right)\end{array}$ & $\begin{array}{c}\text { Error } \\
(\%)\end{array}$ & $\begin{array}{c}\mathrm{C} \\
\left(\mathrm{g} \cdot \mathrm{m}^{-2} \cdot \mathrm{yr}^{-1}\right)\end{array}$ & $\begin{array}{c}\text { C estim. } \\
\left(\mathrm{g} \cdot \mathrm{m}^{-2} \cdot \mathrm{yr}^{-1}\right)\end{array}$ & $\begin{array}{c}\mathrm{CO}_{2} \\
\left(\mathrm{Mg} \mathrm{ha}^{-1} \cdot \mathrm{yr}^{-1}\right)\end{array}$ & $\begin{array}{c}\mathrm{CO}_{2} \text { estim. } \\
\left(\mathrm{Mg} \cdot \mathrm{ha}^{-1} \cdot \mathrm{yr}^{-1}\right)\end{array}$ \\
\hline 1 & 311.5 & 308.6 & -0.9 & 131.8 & 130.5 & 4.8 & 4.8 \\
\hline 2 & 361.6 & 337.6 & -6.7 & 153.0 & 142.8 & 5.6 & 5.2 \\
\hline 3 & 714.3 & & & 302.2 & & 11.1 & \\
\hline 4 & 393.8 & 411.0 & 4.4 & 166.6 & 173.8 & 6.1 & 6.4 \\
\hline 5 & 398.7 & 352.2 & -11.7 & 168.6 & 149.0 & 6.2 & 5.5 \\
\hline 6 & 377.0 & 406.8 & 7.9 & 159.5 & 172.1 & 5.8 & 6.3 \\
\hline 7 & 240.6 & 241.6 & 0.4 & 101.8 & 102.2 & 3.7 & 3.7 \\
\hline 8 & 499.3 & 372.2 & -25.5 & 211.2 & 157.4 & 7.7 & 5.8 \\
\hline
\end{tabular}

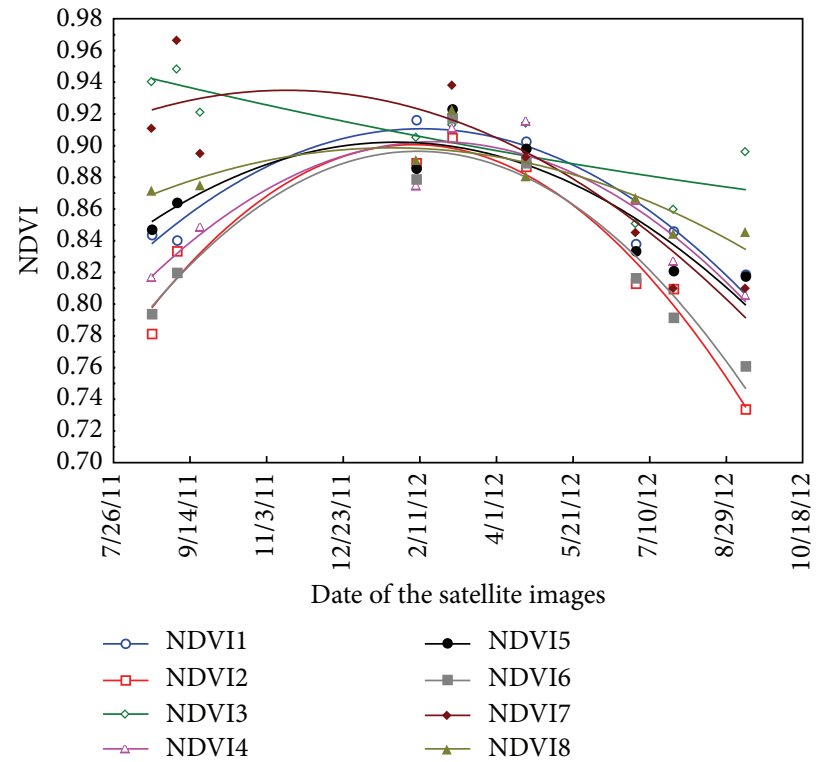

FIGURE 9: NDVI with second-degree polynomial tendency for each fragment.

\section{Discussion}

In plant species, the phenology is divided into sprouting, blooming, fructification, senescence, and leaf fall stages. The sprouting or leaf renewal and the senescence or leaf fall reflect in the LAI and in the NDVI in seasonal forests. Some deciduous forest typology has three stages. The first is the leaf production period, followed by the second with a stable leaf area period, and the third is the senescence (leaf fall). Wang et al. [16] observed this three stage pattern. In this present work, the stable leaf area period was not observed.

Another point is that there is divergence between authors with respect to the linear or nonlinear relationships between LAI and NDVI $[12,16,21,23]$. In this study, the relationship is nonlinear and the tendency changes according to the stage (Figure 4).

Soudani et al. [7] verified the annual NDVI behavior with high precision, which was obtained on a daily basis in the field, in seasonal forest sites (European beech). They observed two stages. Firstly, it was the leaf season, from mid spring until October, during which the sprouting, development, and maturation take place. The second stage is the dormancy stage, from the end of October until the winter. This is when the yellowing, the senescence, and the leaf fall take place. The leaf season starts with a NDVI jump from minimum to maximum in 26 to 30 days, followed by a slight decrease during the summer period, when another brusque change occurs, the reduction is in the beginning of the fall. The behavior presented by Soudani et al. [7] is different from that predicted by us, but in their work did not there test of dynamics of the South American forest sites. On the other hand, our NDVI data follow the LAI measured in the field, with a displacement explained by the distance between the yellowing of the leaves and their posterior fall.

A future investigation with a spectroradiometer and a greater temporal resolution would confirm the tendency in forest sites with seasonality by water regime.

By modeling the deciduous dynamics behavior, LAI and NDVI, good adjustments were obtained with the polynomial equations for a period of 13 months. The relationship of LAI and NDVI adjusted by these curves shows a behavior similar to that found in Figure 6 in Wang et al. [16], referring to patch $\mathrm{AB}$ and $\mathrm{CD}$ with the leaf production stage, with a faster LAI ascension and relatively slow NDVI, and the deciduous stage, with gradual reduction in both variables.

By calculating the water balance for the leaf accumulation periods, a good correlation was achieved with the deciduousness change rates. It was verified that when the rainy season ends, the deciduousness rate presents a strong correlation with the water deficit increase, as shown in Figure 6. This evidence was a key to choose the variable, "water deficit," to explain deciduous dynamics. The water excess is a variable with little explanatory capability in this process, since the fluctuation of the water excess above the soil water availability does not interfere in the plants response and in the way the deciduousness is driven by the water deficiency. In the construction of a predictive model for the deciduousness dynamics in the seasonal forest driven by the rainfall regime, the LAI and the NDVI complement themselves as predictive variables. It is not possible to eliminate the LAI in this model. 


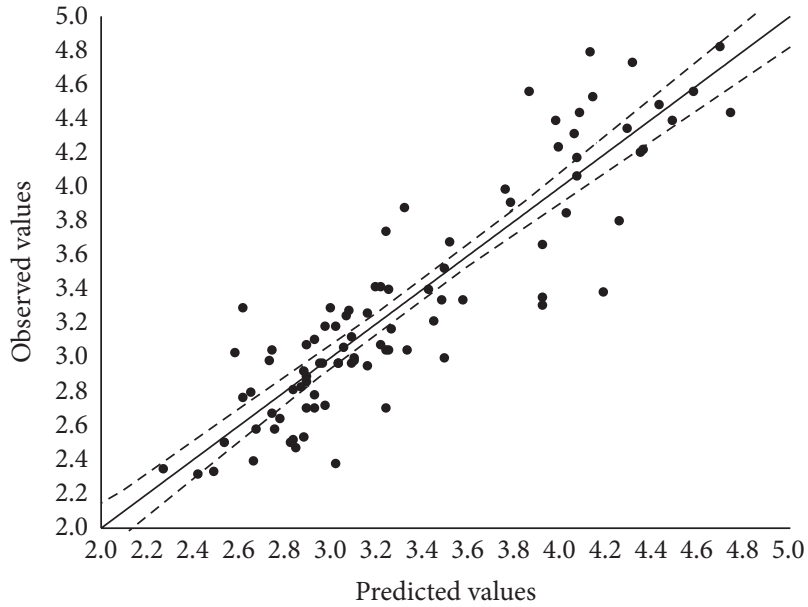

(a)

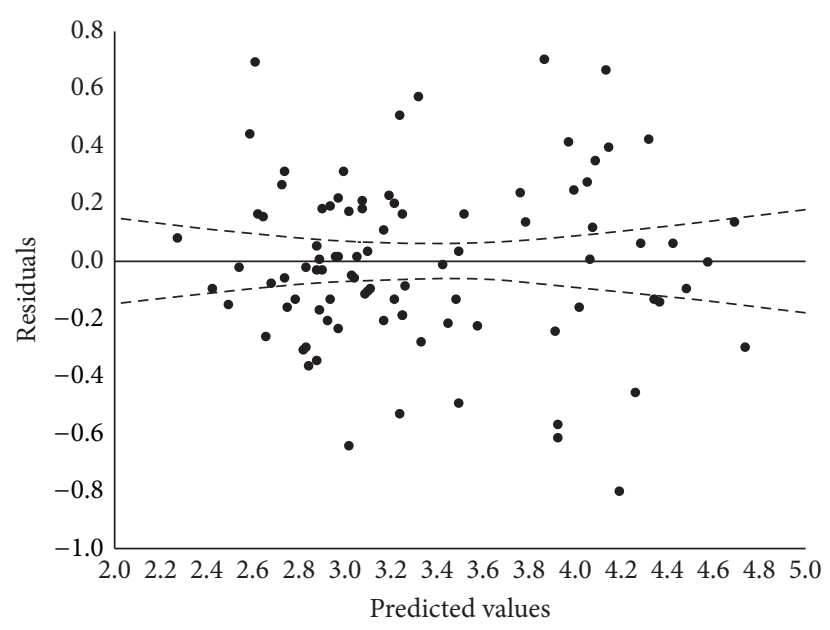

(b)

Figure 10: (a) Observed data in function of the predicted data for the adjusted equation; (b) distribution of residuals in function of the predicted data. P.S.: logarithmic data.

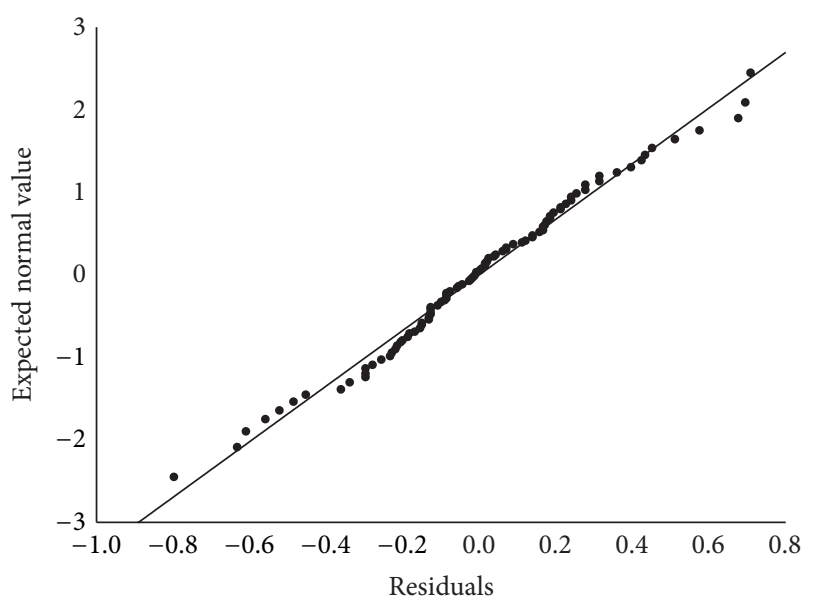

FIGURE 11: Presupposition of the normality of errors.

The use of medium resolution orbital images for such research succeeds for many forest fragment sizes. However, they demand a great effort to reach consistent atmospheric corrections. The products of the MODIS sensor have incompatible resolution with many forest fragments. In this experiment, it was not possible to use them. However, in larger forest areas, its application may go without LAI measurement in the field.

Another observation refers to the LAI calculation from $\mathrm{NDVI}_{\text {MODIS }}$, based on the results presented in Figure 5 in Potithep et al. [29]. The displacement between LAI based on $\mathrm{VI}_{\text {MODIS }}$ and the LAI in situ presented in the graphic may be due to the calculation manner of the variable that has origin in vegetation index. LAI is the leaf area detector with few variations in relation to its physiologic state, senescence vigor, and is more sensitive to leaf fall, while VI is sensitive to the chlorophyll degradation, with the yellowing and discoloration of the leaf before its fall. Another issue is that the startup of the LAI $\mathrm{I}_{\text {MODIs }}$ anticipates itself to LAI in situ. Potithep et al. [29] attributed this to the forest soil interference due to herbaceous sprouting, justifying the early LAI growth values generated by MODIS first, than the real LAI value. The same delay behavior between $\mathrm{LAI}_{\mathrm{MODIS}}$ and LAI in situ was observed by Ahl et al. [42].

One of the advantages of making predictions by periods (the period adopted was monthly), using a model with acceptable dispersion, however, without bias, is the compensation of errors in the totalization of the results for a longer period. This raises the precision, which was confirmed by the annual $\mathrm{CO}_{2}$ fixation estimate in each fragment. Smaller periods of 15 days, and longer continuous monitoring, longer than a year are recommended to validate this model.

The equation was developed for semideciduous seasonal forests of the Atlantic Forest, with deciduousness driven by the tropical climatic seasonality, with similar parameters to those measured in these sites. Its objective is to estimate the annual production of the litterfall leaves, which constitutes another $\mathrm{CO}_{2}$ capture mechanism that is not yet accounted for in the carbon sequestration projects, additional to the continuous increase of the aerial and root biomass.

\section{Conclusions}

The deciduousness phenomenon in semideciduous seasonal forest was measured, and relationships between the climatic biophysics and orbital variables were found, allowing the modeling and acquisition of leaf fall and annual $\mathrm{CO}_{2}$ capture estimates. The possible use of the quadratic model for the deciduousness behavior was confirmed for short periods, those of 13 months. For longer periods, the sigmoidal models are adequate. The hypotheses of the detection and modeler of the inverted relation of the LAI and NDVI with the deciduousness were confirmed. Temporal relationships between NDVI and LAI were revealed, indicating that the correlation 


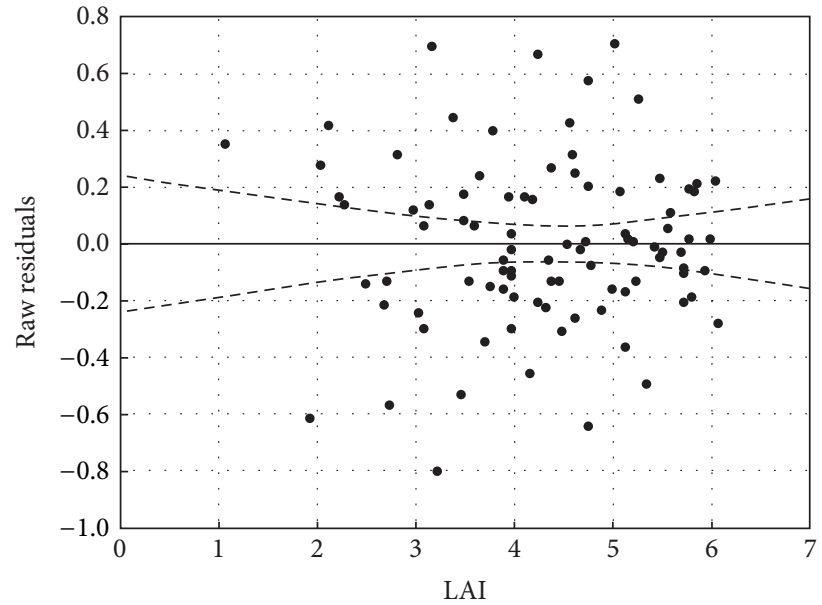

(a)

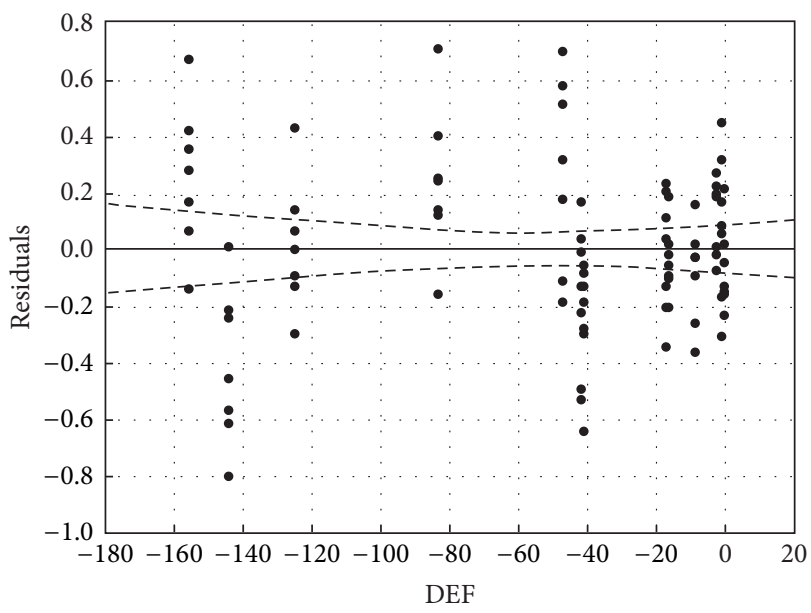

(c)

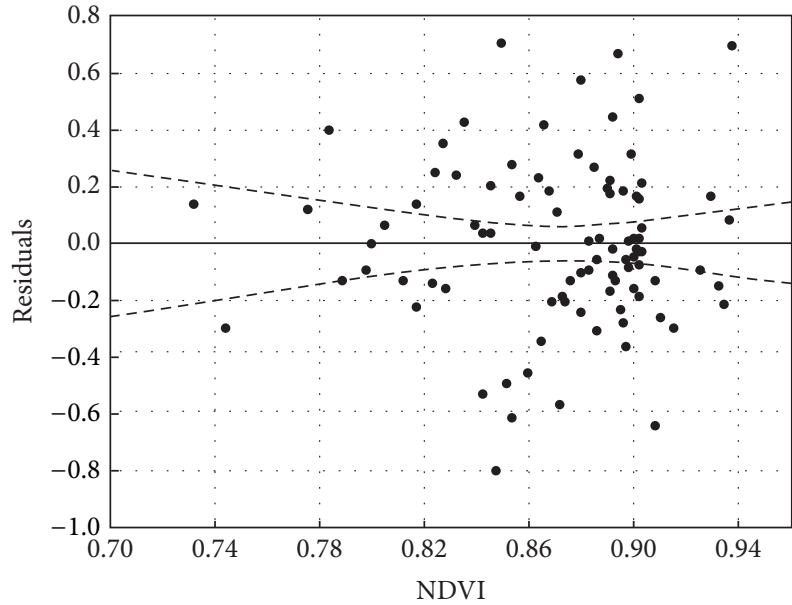

(b)

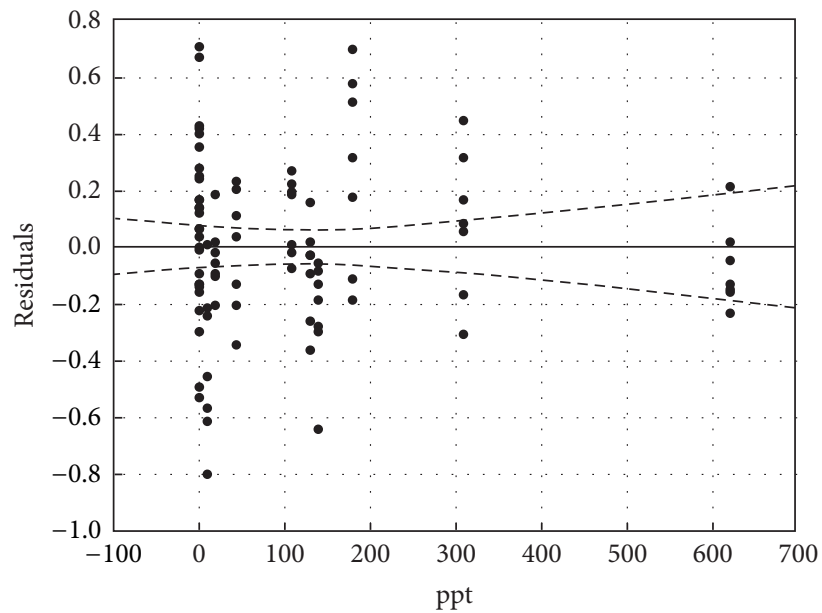

(d)

FIGURE 12: Scatter of the residuals with LAI, NDVI, water deficiency, and ppt.

is nonlinear. The NDVI is showed to be correlated with the deciduousness as an explanatory variable. For the perennial forest site, this perspective of prediction was not successful due to the subsurface water availability. This procedure to estimate the annual production of renewed leaves with orbital and climatological data is not yet viable on a large scale for a large part of the forest fragments due to the necessity of the LAI measurement. In the MODIS use hypothesis, in these situations, there is a limitation to the fragments with areas noncompatible with their resolution. The modeling of the litterfall production, with the intention to contribute to the study of nutrient cycling, carbon sequestration, and forest fragment biomass productive capacity is possible on a small scale. However, it still needs validation. Deciduous seasonal forest fragments are able to capture between 4 to 8 tons of $\mathrm{CO}_{2}$ per hectare/year, only due to the deciduousness phenomenon, which will depend on the regeneration stage and forest conservation, besides the other biophysical factors.

\section{Conflict of Interests}

The authors declare that there is no conflict of interests regarding the publication of this paper.

\section{Acknowledgments}

This study is a result of Project CNPq 561864/2010-1 "Parameters of forest fragmentation as subsidy for the environment quality and recovery of degraded environments," which is a sponsor of this research. The authors would like to thank the intern team who participated in the acquisition of the data and made the monitoring possible, Marielle Raid, Gabriel Miranda, Sâmara E. F. Carvalho, Marcos Chamon, and the botanists Andréa Fonseca Silva and Morgana Flávia Rodrigues Rabelo, of Epamig Herbario, for the identification of the species, Douglas Soares, Felipe Guimarães and Dauler Gomes that helped me on instalation and some mensuraments of this forest inventory and Antonio Claudio da Silva 
Barros and Ross Thomas for reviewing the language in this manuscript.

\section{References}

[1] E. J. Brun, M. V. Schumacher, and S. Vaccaro, "Produção de serapilheira e devolução de nutrientes em três fases sucessionais de uma Floresta Estacional Decidual no município de Santa Tereza (RS)," in Anais do Simpósio de Fertilização e Nutrição Florestal, Piracicaba, p. 348, 364ESALQ, Piracicaba, Brazil, 1999.

[2] K. H. Feger and S. Raspe, "Ökosystemforschung im chwarzwald: auswirkungen von atmogenen einträgen und Restabilisierungsmassnahmen auf den Wasser-und Stoffhaushalt von Fichtenwäldern," in Verbundprojekt Arinus, S. Raspe, K. H. Feger, and H. W. Zotil, Eds., pp. 1-18, Umweltforschung in Baden-Württenberg, Landsberg, Germany, 1998.

[3] G. C. Cunha, Aspectos da ciclagem de nutrientes em diferentes fases sucessionais de uma floresta estacional do Rio Grande do Sul [Dissertation], Escola Superior de Agricultura "Luiz de Queiroz", Piracicaba, Brazil, 1997.

[4] F. M. S. Moreira and J. O. Siqueira, Microbiologia e bioquímica do solo, UFLA, Lavras, Brazil, 2002.

[5] L. R. Barichello, M. V. Schumacher, H. L. M. Vogel, and J. S. Dallago, "Quantificação dos nutrientes no solo e serapilheira de diferentes estágios sucessionais em um sistema de agricultura migratória," 2000, Resumos expandidos da Reunião Sul Brasileira de Ciência do Solo, Pelotas (CD-ROM).

[6] F. Poggiani and M. V. Schumacher, "Ciclagem de nutrientes em florestas nativas," in Nutrição e fertilização florestal, J. L. M. Gonçalves and V. Benedetti, Eds., pp. 287-308, Instituto de Pesquisas Florestais, Piracicaba, Brazil, 2000.

[7] K. Soudani, G. Hmimina, N. Delpierre et al., "Ground-based Network of NDVI measurements for tracking temporal dynamics of canopy structure and vegetation phenology in different biomes," Remote Sensing of Environment, vol. 123, pp. 234-245, 2012.

[8] F. G. Konig, M. V. Schumacher, E. J. Brun, and I. Seling, "Avaliação da sazonalidade da produção de serapilheira numa floresta Estacional Decidual no município de Santa Maria-RS," Revista Árvore, vol. 26, no. 4, pp. 429-435, 2002.

[9] M. Ludeke, A. Janecek, and G. H. Kohlmaier, "Modelling the seasonal $\mathrm{CO}_{2}$ uptake by land vegetation using the global vegetation index," Tellus B, vol. 43, no. 2, pp. 188-196, 1991.

[10] C. J. Silva, F. A. Lobo, M. E. Bleich, and L. Sanches, "Contribuição de folhas na formação da serrapilheira e no retorno de nutrientes em floresta de transição no norte de Mato Grosso," Acta Amazonica, vol. 39, no. 3, pp. 591-600, 2009.

[11] X. Zhang, M. A. Friedl, C. B. Schaaf et al., "Monitoring vegetation phenology using MODIS," Remote Sensing of Environment, vol. 84, no. 3, pp. 471-475, 2003.

[12] R. Fensholt, I. Sandholt, and M. S. Rasmussen, "Evaluation of MODIS LAI, fAPAR and the relation between fAPAR and NDVI in a semi-arid environment using in situ measurements," Remote Sensing of Environment, vol. 91, no. 3-4, pp. 490-507, 2004.

[13] X. Zhang, M. A. Friedl, C. B. Schaaf, and A. H. Strahler, "Climate controls on vegetation phenological patterns in northern midand high latitudes inferred from MODIS data," Global Change Biology, vol. 10, no. 7, pp. 1133-1145, 2004.

[14] M. Doiron, P. Legagneux, G. Gauthier, and E. Lévesque, "Broadscale satellite Normalized Difference Vegetation Index data predict plant biomass and peak date of nitrogen concentration in Arctic tundra vegetation," Applied Vegetation Science, vol. 16, pp. 343-351, 2013.

[15] L. Fan, Y. Gao, H. Brück, and C. Bernhofer, "Investigating the relationship between NDVI and LAI in semi-arid grassland in Inner Mongolia using in-situ measurements," Theoretical and Applied Climatology, vol. 95, no. 1-2, pp. 151-156, 2009.

[16] Q. Wang, S. Adiku, J. Tenhunen, and A. Granier, "On the relationship of NDVI with leaf area index in a deciduous forest site," Remote Sensing of Environment, vol. 94, no. 2, pp. 244-255, 2005.

[17] M. Maki, K. Nishida, N. Saigusa, and T. Akiyama, "Evaluation of the relationship between NDVI and LAI in cool-temperate deciduous forest," in Asian Association on Remote Sensing, Proceedings of the Asian Conference on Remote Sensing and Asian Space Conference, Ha Noi, Vietnam, 2005.

[18] A. C. Xavier and C. A. Vettorazzi, "Monitoring leaf area index at watershed level through NDVI from landsat-7/ETM+ data," Scientia Agricola, vol. 61, no. 3, pp. 243-252, 2004.

[19] T. C. C. Costa, L. J. O. Accioly, M. A. J. Oliveira, N. Burgos, and F. H. B. Silva, "Phytomass mapping of the "Seridó Caatinga" vegetation by the plant área and the normalized difference vegetation indeces," Scientia Agricola, vol. 59, no. 4, pp. 707-715, 2002.

[20] D. P. Turner, W. B. Cohen, R. E. Kennedy, K. S. Fassnacht, and J. M. Briggs, "Relationships between leaf area index and Landsat TM spectral vegetation indices across three temperate zone sites," Remote Sensing of Environment, vol. 70, no. 1, pp. 52-68, 1999.

[21] T. N. Carlson and D. A. Ripley, "On the relation between NDVI, fractional vegetation cover, and leaf area index," Remote Sensing of Environment, vol. 62, no. 3, pp. 241-252, 1997.

[22] S. Amaral, J. V. Soares, D. S. Alves et al., "Relações entre Índice de Área Foliar (LAI), Área Basal e Índice de Vegetação (NDVI) em relação a diferentes estágios de crescimento secundário na Floresta Amazônica em Rondônia," in Anais do VIII Simpósio Brasileiro de Sensoriamento Remoto, pp. 485-489, INPE, São José dos Campos, 1996.

[23] M. A. Friedl, F. W. Davis, J. Michaelsen, and M. A. Moritz, "Scaling and uncertainty in the relationship between the NDVI and land surface biophysical variables: an analysis using a scene simulation model and data from FIFE," Remote Sensing of Environment, vol. 54, no. 3, pp. 233-246, 1995.

[24] M. A. Spanner, L. L. Pierce, S. W. Running, and D. L. Peterson, "The seasonality of AVHRR data of temperate coniferous forests: relationship with leaf area index," Remote Sensing of Environment, vol. 33, no. 2, pp. 97-112, 1990.

[25] Li-Cor, LAI-2200 Plant Canopy Analyzer: Instruction Manual, Li-Cor Biosciences, Lincoln, UK, 3rd edition, 2011.

[26] G. Zheng and L. M. Moskal, "Retrieving leaf area index (LAI) using remote sensing: theories, methods and sensors," Sensors, vol. 9, pp. 2719-2745, 2009.

[27] J. M. Welles and S. Cohen, "Canopy structure measurement by gap fraction analysis using commercial instrumentation," Journal of Experimental Botany, vol. 47, no. 302, pp. 1335-1342, 1996.

[28] S. T. Gower, C. J. Kucharik, and J. M. Norman, "Direct and indirect estimation of leaf area index, $\mathrm{f}(\mathrm{APAR})$, and net primary production of terrestrial ecosystems," Remote Sensing of Environment, vol. 70, no. 1, pp. 29-51, 1999.

[29] S. Potithep, S. Nagai, K. N. Nasahara, H. Moraoka, and R. Suzuki, "Two separate periods of the LAI-Vis relationships 
using in situ measurements in a deciduous broadleaf forest," Agricultural and Forest Meteorology, vol. 169, pp. 148-155, 2013.

[30] M. Kale, S. Singh, and P. S. Roy, "Estimation of Leaf Area Index in dry deciduous forests from IRS-WiFS in central India," International Journal of Remote Sensing, vol. 26, no. 21, pp. 48554867, 2005.

[31] L. F. Watzlawick, A. A. Ebling, A. L. Rodrigues, Q. J. I. Veres, and A. M. Lima, "Variação nos teores de carbono orgânico em espécies arbóreas da floresta ombrófila mista," Floresta e Ambiente, vol. 18, no. 3, pp. 248-258, 2011.

[32] USDA, "Soil taxonomy: a basic system of soil classification for making and interpreting soil surveys," in Agriculture Handbook, 1999.

[33] R. G. Allen, L. S. Pereira, D. Raes, and M. Smith, "Crop evapotranspiration: guidelines for computing crop water requirements," Irrigation and Drainage Paper 56, FAO, Rome, Italy, 1998.

[34] A. R. Pereira, L. R. Angelocci, and P. C. Sentelhas, Agrometeorologia: fundamentos e aplicações práticas, Agropecuária, Guaíba, Brazil, 2002.

[35] J. B. Miller, "A formula for average foliage density," Australian Journal of Botany, vol. 15, pp. 141-144, 1967.

[36] P. S. Chavez Jr., "An improved dark-object subtraction technique for atmospheric scattering correction of multispectral data," Remote Sensing of Environment, vol. 24, no. 3, pp. 459-479, 1988.

[37] S. Gürtler, J. C. N. Epiphanio, A. J. B. Luiz, and A. R. Formaggio, "Planilha Eletrônica para o cálculo da reflectância em imagens TM e ETM+ Landsat," Revista Brasileira De Cartografia, vol. 57, no. 2, pp. 162-167, 2005.

[38] B. C. Forster, "Derivation of atmospheric correction procedures for LANDSAT MSS with particular reference to urban data," International Journal of Remote Sensing, vol. 5, no. 5, pp. 799817, 1984.

[39] J. R. Eastman, “ATMOSC, IDRISI Help System, Accessed in IDRISI Taiga, Clark University, Worcester, UK, 2009.

[40] R. K. Gupta, T. S. Prasad, and D. Vijayan, "Relationship between LAI and NDVI for IRS LISS and LANDSAT TM bands," Advances in Space Research, vol. 26, no. 7, pp. 1047-1050, 2000.

[41] L. M. T. Oliveira, G. B. Franca, R. M. Nicacio et al., "A study of the El Niño-Southern oscillation influence on vegetation indices in Brazil using time series analysis from 1995 to 1999," International Journal of Remote Sensing, vol. 31, no. 2, pp. 423437, 2010.

[42] D. E. Ahl, S. T. Gower, S. N. Burrows, N. V. Shabanov, R. B. Myneni, and Y. Knyazikhin, "Monitoring spring canopy phenology of a deciduous broadleaf forest using MODIS," Remote Sensing of Environment, vol. 104, no. 1, pp. 88-95, 2006. 

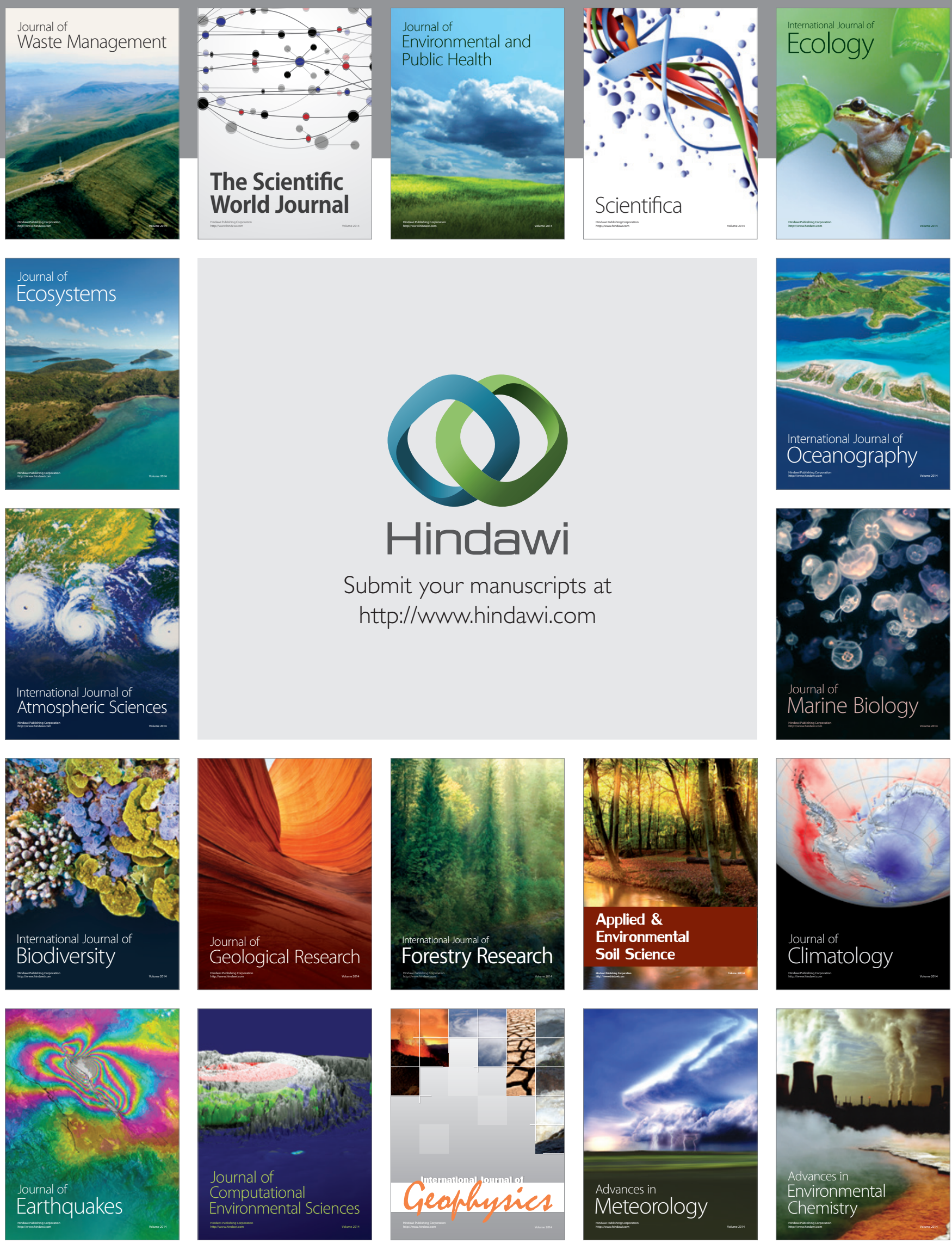